\title{
THE FIELD OF CRIPPLE CARE
}

\section{The National Council for the Care of Cripples in South Africa}

THE practising physiotherapist. particularly if attuched to a provincial hospital. must wonder whall good purpose is served by a voluntary organisation such as the National Council for the Care of Cripples with its ninc Regional Cripple Care Associations, and how in any way she is concerned with it.

\section{Early Days.}

To answer the question, one must delve back into history a bit.

Prior to 1937 there was but a sniall group of people in Cape Town, the O.F.S. and the committees for the Hope Homes in Johannesburg. devoting their energies to the Care of Cripples in South Africa.

There were but four or five Orthopaedic surgeons as ailable to serve the Union and South West Africia.

Apart from one or two trained Orthopacdic nurses in private institutions there were none in the country. A similar position existed with Orthopaedic technicians

Another serious difficulty in those carly days was the shortage of beds for long term orthopaedic patuents, of uhom many were children. This meitnt that the benefit from the skilled surgical attention that was alialable. was frequently minimised.

The samc applied to the potential benefits of sound orthopaedic nursing, occupational therapy and the use of physiotherapy in the treatment programme

\section{Lord Nuffield.}

It was an uphill struggle but in 1937 due to more than one approach being made to Lord Nuffield, a munificent gift of over $\$ 100,000$ was made to South Africa by this great man. to stinulate interest in the work for the Care of Cripples, both on the levels of voluntary organisations and Government Departments.

Lord Nuffield's desire was for a living organisation rather than that this money be spent prosiding hospitals.

An institution would almost entirely lose its value. without trained personnel being available, and without a network of services leading up to hospitalisation and to the vital after-care of Orthopaedic patients discharged from huspitals.

Thus it was just before the Second World War that a memorandum prepared for the Nuffield Trustees indicated imong other things that the following was essential for South Africa.

1. One co-ordinated Cripple Care organisation to cover the whole Union, with an Agreed policy. Which should as far as possible influence Provincia! Government Adninistration in respect of Cripples.

2. This would require a National Council, and provincial committees (or associations).

3. Suitable Orthopaedic Hospitals and orthopaedic depart. ments in all first grade hospitals, with specialist staff and financial provision for this

4. The need was acute for Pre-graduate teaching of Orthopaedic Princıples in the Universitics. and Post-graduate training in orthopaedic surgery.

5. Workshops for the plovision of appliances: out-stations (orthopaedic cliniss including those in Rural arcas) and feeder services.

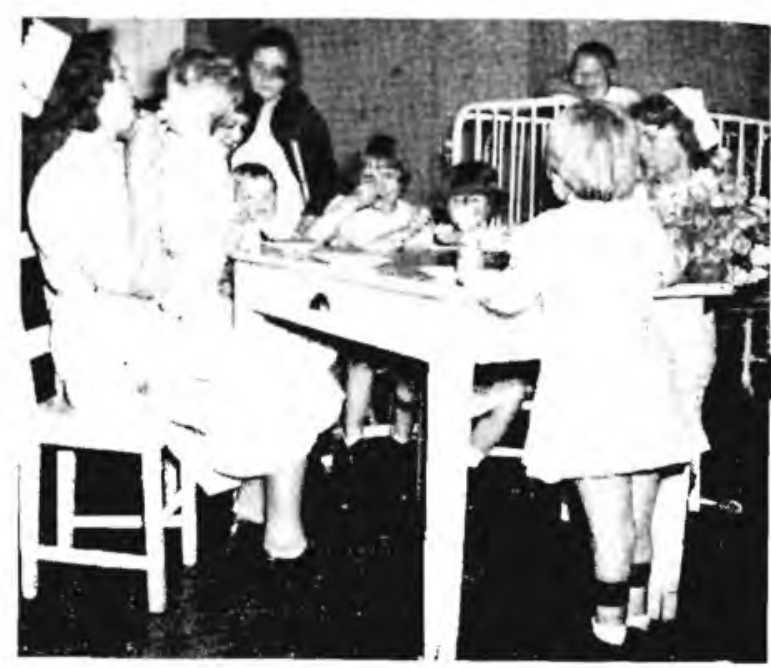

Weal time in an Orthopacdic Home. Good nourishing tood. sound treatment and loving care and efficient nursing help these soungsters on the long road to habilitation: it takes a tcam work of the therapists. the nurses. the teacher. the medical personucl and voluntary orsanisaltion bebind them to produce the final results.

In addition educational facilıies for children in orthopaledic wards. Wals required especially in long lerm cases, and in residential schools and for home-bound cascs because residential or hospital accommodation wals alleady overcrowded.

6. Physical rehabilitation without economic rehabilitation left patients to face a world which labelled a patient with any residual crinpling as something for the scrap heap. Employers therefore required to be educited to the concept of the value of utilizıng partially disabled persons.

National Council for the Care of Cripples in South Africa.

Lord Nuffield's gift could not possibly cover alt of these needs. but having laid the foundation did serve as a stimulus to S.A., and one of the first irems for which the need became increasingly evident was that of a "National Council".

Accordingly in 1939 the National Council for the Care of Cripples in South Africil wals formed with a view to:

I. Ensure a national orthopaedic (Cripple Care) service for Cripples. In order to do this. the council must initiate and also co-ordinate and corrclate such services inaugurated by voluntary bodies, government departments and institutions working in the interest of Cripples: encourage expansion. and help maintain it: formulate and assist in implementing policies since $80^{\circ}$, of permanent Crippling is preventable, promote and support measures for carly discovery and treatment. and to act in an advisory capacity.

2. To promote schemes for the treatment. education, training, employment and general welfare of cripples:

3. To be the official channel for communication in matters of general policy between constituent Cripple Care bodies, the Government and Provincial authorities. 


\section{Special Grants.}

Since then Council has madc great stricles. Barticukarly after the war. and among olher things hats prosided grants for the subsidized training of:

Orthopacdic surgeons. orthopaledic nurses, technicians for making and fitting orthopaedic appliances.

Sudsidized salaries for: qualified welfare workers and aftercare sisters doing essential urban, sub-urban and district Cripple Care Work.

Made grants towards: transport of above: establishing Aftercare Homes and maintenance of them: Mission Hospitals and other Institutions engaged in Orthopaedic Services. and lowards eslablishing and maintaining Orthopaedic ciinics: the training of physiolherapy tutors: advanced study overseas in orthopaedics where such was not available to selected persons in this country such as occupational therapists, qualified orthopaedic nurses, and physiotherapists.

\section{Rehabilitation of Cripples.}

This Council takes the initiative and also an active part negotiating with State Departments for services and projects in the welfare of, shall we say, rehabilitation of cripples.

A leading orthopaedic surgeon, who is a member of this Council has said:

"In this sphere of physical disability there are still thousands of cases in S.A. for instance, requiring discovery by survey clinics; reconstruclive surgery to mend the results of accidents and injury; education; vocational training and placement in employment.

Thus although much useful work is being done by voluntary 'Cripple Care', and by Statc and Provincial Departments, there are still many gaps along the assembly line of producing rehabilitated citizens, that urgently need filling.

Survey clinics in areas such as George. Worcester. Thaba Nchu. Wolmaransstad, Ermelo, Standerton, Rustenburg. Pietersburg. Witbank, have shown that in every community there are dozens of disabled persons waiting for an opportunity that does not develop in time for their particular needs.

The deformed fool is discovered at the age of 30 where as it could have been cured at the age of 10 . A man with leprosy was discovered when his hands and feel were covered with septic sores and his hands were so anaesthetic That re-constructive surgery was not worthwhile. The child with the deformed spine is discovered when the deformity has become fixed and cannor be cured. The man who could have been back at work with a good artificial limb potters about for half a life time dragging along a uscless limb but forgetting the use of his brain and his other three healthy extremities. These tragedies are unearthed at decentralized orthopaedic clinics initiated by Cripple Care Associations, with this Council's assistance.

The mechanical age of motorbikes and motor driven gadgets is producing more disabled people than polio or T.B. ever did.

In progressive countries surgical Tuberculosis hospitals are being converted 10 iccident units. In industry there are 250,000 accidents per vear in S.A. -almost a 1.000 accidents per day, costing 21 million man-days per ycar. Life's uncertainty is proverbial. One minute you alre alright. and an hour later you're lying in a hospital bed having a blood transfusion, your life blighted by an accident.

The ability to face disabilities is inherent in all of us. Nature gives us the capacity to face the stresses when we have to face them, but help is required, so that rehabilitation of the disabled persons is the ultimatc aim of the National
Council for the Care of Cripples. We want to sec every disibled person restored to the maximum physical, psychological and social recovery possible.

For this purpose we need trained personnel. The Witwatersrand University needs a professorial chair of traumatic and orthopacdic surgery. The training course for physiotherapists, occupational therapists, radiographers, speech therapists. orthopaledic mechanicians and social workers has to be further developed and expanded. There is a great shortage of these technicians in the field of Rehabilitation."

\section{Present day Activities of Cripple Care Associations.}

Nevertheliss, as contrast with the dearth of 'Cripple Care' activities in 1937. today Councal has nine regional Cripple Care Associations covering the following areas: S.W.A., N. Transvaal, S. Transvaal, O.F.S.. Natal, with the Cape divided in four--Border, Eastern Province, Western Cape and Northern Cape.

These regional associations with direct representation on Council have formed many sub-issociations, or local comnittees throughout their regions in an effort to inaugurate and help to maintain Cripple Care Services in their areas, but there is a vast amount still to be done.

One of the important features in a sound Cripple Care service is early treatment. Many diseases cause crippling as do accidents and some tendencies to deformity are congenital, yct carly treatment in all categories can prevent permanent crippling from developing, in at least $80 \%$ of such patients.



paralved and confired to a wheel-chair for five ycars, it was a wonderiul (a) arianeet arraneed rranspory for him to be whe he mole again. 
Thus finding the cripple or potential cripple, and assisting the patient to obtain correct attention and to follow the case through to satisfactory rehabilitation, (or in the case of a child, habilitation) is one of the important functions of "Cripple Care" in South Africa.

\section{Education of the Public.}

A very vital, but not so well known fact of Council's work, is that of essential publicity to educate the public as to the importance of helping cripples to help themselves. One may say that rehabilitation begins with prevention or finding a cripple and does not end. until the adult is fully established as a self-supporting member of his community.

In the case of a physically handicapped child his physical, and emotional habilitation is not complete until he has been provided with education and sufficient training to enable him to become a satisfactory wage earner.

Films and Publicity.

To disseminate instructive information, this Council maintains a large library of films on Cripple Care to act as an informative stimulus to the general public, and to encourage cripples or parents of cripples to seek treatment, and to persevere with treatment, even though at times it may seem interminable.

Its staff and representatives throughout the Union and S.W.A. give talks and arrange film shows to the general public whenever even a small group can gather together for the purpose.

It issues illustrated pamphlets and for this purpose, with the patients' permission, the staff takes many hundreds of convincing photographs.

A new series of instructional pamphlets has now been initiated, the first one known as "Foot Complaints and Foot Hygiene", which is distributed to the public without charge.

The Council is responsible for a goodly number of publications in the interest of Cripples. It also succeeds in issuing press and radio releases in connection with their welfare.

It is obvious then that the National Council for the Care of Cripples has already assisted in initiating a considerable variety of services, but much more is still to be done.

There are many people in the country who would not today be doing Cripple Care Work if it had not been for the stimulus and acknowledgment, encouragement and financial assistance given by the National Council for the Care of Cripples.

\section{NATIONAL COUNCIL FOR THE CARE OF CRIPPLES.}

Film-_"Dynamic Posture" (16 m.m. sound-colour running time approximately 20 minutes).

This film has been added to the National Council for the Care of Cripples film library and is available on loan for short periods. The film was produced by Beckett Howorth, M.D., in association with the Greenwich Hospital Association and sponsored by the Association for the Aid of Crippled Children, New York.

Its practical approach to the subject of posture in relation to everyday life makes it an instructive film for teachers, scholars and housewives, also suitable for showing to all branches of the medical and para-medical professions and general public.

"Dynamic Posture" is the term used to indicate correct body position in action, and in preparation for action, in order to prevent avoidable strain and jar. Requests for loan of the film should be made to:-

The Film Librarian,

National Council for Care of Cripples,

P.O. Box 10173, Johannesburg.

\section{Easter Stamp Fund Canıpaign.}

There are many great doctors, therapists, orthopaedic mechanicians and social workers who are now devoted to this cause because of the initial interest of our Council.

The Cerebral Palsy work being done in many centres in this country is assisted by a special Division of the National Council.

The Rehabilitation of Coloured disabled in the Cafda Industrial Training scheme in the Cape is another example, where money form the proceeds of the Easter Stamp Fund has made it possible to carry on.

The National Council's income is derived almost entirely from its annual Easter Stamp Campaign, conducted from March lst for several weeks in the larger towns and longer in the country areas.

The field work in many rural clinics, the decentralized services associated with aftercare to persons already treated, the orthopaedic workshops and medical school departments are to some extent indebted to Lord Nuffield for his great gift, are directly and indirectly indebted as well to the public who have from year to year contributed to our annual drive for funds in the Easter Stamp Fund Campaign

While the Council's affiliated cripple care associations receive some subsidies from provincial departments for certain aspects of their work, the Council is dependent on the support of the public for its major work.

From the proceeds of the Easter Stamp Fund, it sets așide a replenishment of its main funds such as a clinic fund, a contingency fund and so on, and thereafter $60 \%$ of the nett proceeds is automatically allocated back to its nine regional associations pro-rata to what is raised in their area, and for use in their region at the discretion of their own committee.

The Council also makes various grantș as enumerated earlier in this article.

The collection of funds is done largely by voluntary workers. The Cripple Care Secretary or her Regional Easter Stamp Organiser in each region rallies a convener in every centre and in every suburb who in turn is asked to gather her friends and their friends together, to implement the sale of Easter Stamps and raise money in every possible way for the Easter Stamp Fund Campaign. The National Council for the Care of Cripples and its Easter Stamp organisation is not unmindful of the active part the physiotherapists have played in assisting in the sale of Easter Stamps for many years, and herewith extends its sincere thanks.

\section{HOOK REVIEW}

\author{
"BREATHING EXERCISES" \\ by G. M. Storey \\ Published by Faber and Faber \\ Cost 8s. 6d. net.
}

Miss Storey's new book "Breathing Exercises" fulfils a great need and will be of value to all physiotherapists.

It is well arranged and very readable, with clear diagrams well situated in relation to the text. The first chapters describe the mechanism of respiration and the factors influencing breathing; and the following chapters discuss and cover the teaching of relaxation and breathing exercises in a variety of conditions.

Details of localized breathing exercises are not given and one would therefore not recommend the book for those on a thoracic surgical unit. However, one is given an excellent general idea of controlled breathing exercises and relaxation which are so important in all treatments, but especially medical cases which are covered very adequately.

This should be a useful book for students and qualified physiotherapists in general departments where the chronic bronchitic and asthmatic patients present such a problem. 